\title{
Crafting a livelihood: local-level trade in mats and baskets in Pondoland, South Africa
}

\author{
Zwoitwa Makhado \& Thembela Kepe ${ }^{1}$
}

The contribution of natural resources to the livelihoods of the rural poor is widely acknowledged, yet not much is known about trade in these resources. This article investigates local-level trade in plantbased mats and baskets in Khanyayo Village, Pondoland, Eastern Cape, focusing on the social aspects of harvesting, resource tenure and trade in Cyperus textilis and products made from it. It explores the way the mat and basket trade contributes to the livelihoods of the rural poor and argues that crafting is mainly the domain of very poor or widowed women, who use it to supplement their diverse and multiple livelihood strategies. Although its cash contribution to the total household income is minimal, crafting is seen by local people as extremely important. However, mat and basket traders face a number of internal and external struggles, which must be understood by policy makers if crafting is to contribute to the fight against poverty in rural areas.

\section{INTRODUCTION}

Plant-based, non-timber craft-making is an important component of rural livelihoods in many parts of the world, especially in poor countries. In South Africa plant-based crafting, along with many other non-timber forest or rangeland products, is widely seen as a significant contribution to the fight against rural poverty. This contribution takes the form of domestic use of these products, thus saving the poor the cost of manufactured alternatives, and trade in the products to generate cash income. While historical and anthropological studies have led the way in documenting details of crafting for domestic purposes (e.g. Hunter, 1979), and botanists have described in detail the various characteristics of the plant resources used (e.g. Cunningham, 1987; Heinsohn \& Cunningham, 1991; Cawe \& Ntloko, 1997), several recent studies have highlighted the incomegenerating aspects of craft-making mainly through trade (Marcus, 2000; Shackleton \& Shackleton, 2000; Rogerson \& Sithole, 2001), as well as through exchange and inkind payment for services rendered (Kepe, 2003). Nevertheless, if craft-making is to be taken seriously in policy debates about sustainable economic exploitation of biodiversity to reduce poverty, clarity is needed about how it generates income. Policy-makers and decision-makers may need to know details such as the prevalence of the trade in particular regions of the country, the quantity of products made and sold, the marketing channels and the challenges currently faced by the locally based craft-making industry. Thus far, few South African studies have paid attention to these details.

Using a village case study from Pondoland in the Eastern Cape Province, this article complements earlier studies dealing with craft-making, by presenting and analysing details of village-based trade in crafts. Cyperus textilis (uluzi - singular, imizi - plural)

\footnotetext{
${ }^{1}$ Respectively, graduate student at the Programme for Land and Agrarian Studies, University of the Western Cape, Bellville, South Africa, and Assistant Professor, Department of Geography, University of Toronto at Scarborough, Canada. The authors gratefully acknowledge financial support from the South Africa-Netherlands Research Programme on Alternatives in Development (SANPAD), and comments on an earlier draft by Sheona Shackleton.
} 
is by far the most used plant species in local craftwork. This is an evergreen, water-loving, grasslike plant (sedge) whose stems (culms) can grow up to three metres high. The four items made from imizi are the sitting mat (ikhuko or icantsi); the sleeping mat, also known as ikhuko, but two or three times bigger than the sitting mat; the food mat or isithebe; and collecting baskets (iingceke) (Kepe, 2003). This article has four main sections. Following this introduction, Section 2 discusses the study area and research design, Section 3 presents the findings of the study and Section 4 discusses these findings and concludes.

\section{THE STUDY AREA AND RESEARCH DESIGN}

This article is based on a case study of Khanyayo Village, situated in the Pondoland region of the Wild Coast, Eastern Cape Province. This area, formerly part of the Transkei Bantustan, is characterised by high levels of poverty, extremely poor infrastructure and high unemployment. The area is inhabited by the Khanyayo people, who speak a Xhosa dialect (isiMpondo). The communal settlement comprises seven small sections or sub-villages that make up Khanyayo Administrative Area. These are KwaZitha, Mdumazulu, Mgwedlweni, Sicambeni, Ngwenyeni, Nayntsentse and Njanda. A sub-headman, who reports to the headman of the Khanyayo Administrative Area, heads each sub-village. The inhabitants generate their livelihoods through a mixture of small-scale farming, the collection of a range of natural resources and a range of off-farm sources, including remittances, formal employment and pensions. Even though the area receives a mean annual rainfall of $1200 \mathrm{~mm}$, crop production is limited by poor soil, as well as social and economic factors. This encourages local people to broaden the way they use the local environment, by exploiting the floristically diverse local vegetation for livelihood purposes.

Fieldwork for the study was conducted over a two-month period, spread out between October 2003 and April 2004, including a continuous three-week period in April 2004. The main tool for data collection was a survey administered to 52 people who were identified by other villagers as being involved in the craft-making trade. The questionnaire covered the demographic profile of people involved, the extent of their involvement in the craft-making activity, the production and marketing process and the challenges faced by local craft-makers. The survey data was analysed using SPSS (Statistical Package for Social Sciences) to generate frequencies and means. Since the sample size was small, no attempt was made to expand the analysis beyond this.

In addition to the survey, a range of qualitative research methods was used to gain insight into many issues that could not be captured by the questionnaire. These included transect walks and resource mapping with villagers to learn about the places where the material used for crafting is harvested, focus group interviews with weavers, semi-structured interviews with key informants, and participant observation during day-to-day activities in the village.

\section{FINDINGS}

\subsection{Demographic profile}

Two kinds of people, producers and traders, are involved in mat and basket trading in Khanyayo. Producers harvest raw materials and weave products primarily for home use or to offer as gifts, and traders sell the products. The producers may either harvest the raw material themselves or obtain it from others through purchase with cash or through various forms of exchange. Of the 52 people involved in craft-making, 65 per cent 
described themselves as traders and 35 per cent as producers. The respondents were almost exclusively women: 50 females and only two males. Local informants report that even though craft-making with grass products has historically been an exclusively female activity, the high level of unemployment has seen many men becoming involved in what are traditionally women-only roles, so long they can earn cash. However, when men become involved in such 'women's activities', local informants argue, they tend to choose tasks that can be performed behind the scenes. For example, in craft-making men would be involved in harvesting the raw material if it was grown near their homes.

The average age of the respondents was 56 years $(55.9 \pm 2.1)$. About 80 per cent were over the age of 40; only one was older than 80, and only nine (about 17 per cent) were younger than 40 . It can be concluded that middle-aged women and older women dominate in the mat and basket trade in Khanyayo. Local informants argue that the age profile of people involved in craft-making makes sense, as younger women are most likely to be too occupied with other household activities, such as raising children; whereas older women have often passed that stage, and more often than not have older children or daughters-in-law who could do most of the household chores. As for the marital status of the people involved in crafting, 28 were widowed, 17 were married, four were unmarried, two were separated from their spouses and one was cohabiting. The high percentage of widowed respondents was to be expected given that 31 of the interviews were conducted with respondents from female-headed households. Most of the respondents had never been to school, with 35 having had no formal education at all, 16 having had primary education and only one having had secondary education.

Thirty of the households (58 per cent) had more than six household members. The other 22 households had between one and six household members. On average the households were composed of about 50 per cent adults and 50 per cent children. Overall, the mean size of the households in the study was eight people $(8.01 \pm 0.6)$.

In terms of employment, the majority of households (54 per cent) had no household member with a formal job, compared to 46 per cent of households who had members with jobs. Of the households with members who had formal jobs, 27 per cent had at least one member with a job, 11 per cent had two members with jobs, 6 per cent had three members with jobs and only 2 per cent had four members with a job (see Table 1).

As mentioned earlier, government grants such as pensions are important sources of cash income locally. In fact, about 64 per cent of the respondents said the old age pension was the most important source of household income and only 10 per cent said selling crafts was the most important. The rest said government grants in combination with the sale of

Table 1: Number of employed household members

\begin{tabular}{lc}
\hline Number of employed household members & Percentage \\
\hline 0 & $54 \%$ \\
1 & $27 \%$ \\
2 & $11 \%$ \\
3 & $6 \%$ \\
4 & $2 \%$ \\
Total & $\mathbf{1 0 0 \%}$ \\
\hline
\end{tabular}


natural resource products, including medicinal plants, were important components of their household income.

Table 2 shows that the total monthly income of respondent households ranged from R20.00 to R6740.00 per month, with a mean of about R927 (R926.90 \pm 146.9). Of respondents' households, 17 (33 per cent) had monthly incomes of between R601 and R900 and 14 (27 per cent) earned less than R300 per month. Almost all respondents (50) considered their households to be living in poverty. However, using official poverty measures (May, 2001), only 38 households (73 per cent) could be thus categorised, as their total household income was less than R1000 per month. Table 3 shows the percentage the mat and basket trade contributes to the households' total monthly income. (Note that only traders, numbering 34, are included in Table 3.)

As can be observed from Table 3, with the exception of a few households (e.g. numbers $3,6,10,26$ and 32), the contribution of craft-making income to the total household income is relatively minimal. The majority of households considered the income supplementary; however, this is not to say that there are no households that consider the income critical. During interviews, several respondents claimed that the income from craft, albeit small and only complementary, would be very difficult to replace if it were lost, and that such a loss could result in significant shortfalls in the income needed by the household per month.

\subsection{The making of mats and baskets: resources and the process}

A completed mat or basket involves several resources and processes. Hence this section's focus on the dynamics of access to and control over some of the materials used, as well as the crafting processes involved. Both plant-based and synthetic resources are crucial, but $C$. textilis, the plant material used in making mats and baskets, was regarded as the important resource for craft-making.

\subsubsection{Characteristics, location and ownership of imizi}

Kepe (2002) notes that $C$. textilis (imizi) needs adequate water to survive, so it thrives in areas that are always moist, such as streams and gardens that are watered on a regular basis. The length of the stems, which can range from one to three metres, often determines what each harvested batch is used for. For example, imizi for making sleeping

Table 2: Household monthly income

\begin{tabular}{|c|c|c|c|c|c|c|c|c|c|c|c|c|}
\hline \multirow{3}{*}{$\begin{array}{l}\text { Sub-village } \\
\text { Kwa-zitha }\end{array}$} & \multicolumn{12}{|c|}{ Income categories } \\
\hline & \multicolumn{2}{|c|}{$<\mathbf{3 0 0}$} & \multicolumn{2}{|c|}{$301-600$} & \multicolumn{2}{|c|}{$601-900$} & \multicolumn{2}{|c|}{ 901-1800 } & \multicolumn{2}{|c|}{ 1801-3000 } & \multicolumn{2}{|c|}{$>\mathbf{3 0 0 0}$} \\
\hline & $9.6 \%$ & 5 & $0 \%$ & & $5.8 \%$ & 3 & $1.9 \%$ & 1 & $0 \%$ & & $0 \%$ & \\
\hline Mdumazulu & $1.9 \%$ & 1 & $3.8 \%$ & 2 & $0 \%$ & & $3.8 \%$ & 2 & $0 \%$ & & $0 \%$ & \\
\hline Mgwedlweni & $0 \%$ & & $0 \%$ & & $7.7 \%$ & 4 & $0 \%$ & & $3.8 \%$ & 2 & $0 \%$ & \\
\hline Nayintsentse & $5.8 \%$ & 3 & $0 \%$ & & $3.8 \%$ & 2 & $5.8 \%$ & 3 & $0 \%$ & & $1.9 \%$ & 1 \\
\hline Ngwenyeni & $3.8 \%$ & 2 & $0 \%$ & & $3.8 \%$ & 2 & $0 \%$ & & $0 \%$ & & $0 \%$ & \\
\hline Njanda & $3.8 \%$ & 2 & $0 \%$ & & $1.9 \%$ & 1 & $1.9 \%$ & 1 & $0 \%$ & & $0 \%$ & \\
\hline Sicambeni & $1.9 \%$ & 1 & $7.7 \%$ & 4 & $9.6 \%$ & 5 & $5.8 \%$ & 3 & $1.9 \%$ & 1 & $1.9 \%$ & 1 \\
\hline Total (approx. \%) & $26 \%$ & 14 & $12 \%$ & 6 & $33 \%$ & 17 & $19 \%$ & 10 & $6 \%$ & 3 & $4 \%$ & 2 \\
\hline
\end{tabular}


Table 3: Percentage of monthly income from trading with crafts (in rand)

\begin{tabular}{|c|c|c|c|}
\hline $\begin{array}{l}\text { Household } \\
\text { number }\end{array}$ & $\begin{array}{l}\text { Total monthly cash } \\
\text { income (rand) }\end{array}$ & $\begin{array}{c}\text { Monthly household } \\
\text { income from handicrafts } \\
\text { (rand) }\end{array}$ & $\begin{array}{c}\text { Percentage of total } \\
\text { contributed by mats } \\
\text { and baskets trade } \\
(\%)\end{array}$ \\
\hline 1 & 1650.00 & 100.00 & 6.1 \\
\hline 2 & 360.00 & 60.00 & 16.7 \\
\hline 3 & 550.00 & 190.00 & 34.5 \\
\hline 4 & 940.00 & 100.00 & 10.6 \\
\hline 5 & 380.00 & 40.00 & 10.5 \\
\hline 6 & 1180.00 & 300.00 & 25.4 \\
\hline 7 & 1180.00 & 62.00 & 5.3 \\
\hline 8 & 880.00 & 180.00 & 20.4 \\
\hline 9 & 100.00 & 30.00 & 13 \\
\hline 10 & 80.00 & 50.00 & 62.5 \\
\hline 11 & 790.00 & 50.00 & 6.3 \\
\hline 12 & 120.00 & 38.00 & 31.7 \\
\hline 13 & 280.00 & 70.00 & 25 \\
\hline 14 & 180.00 & 20.00 & 13 \\
\hline 15 & 370.00 & 95.00 & 25.6 \\
\hline 16 & 1120.00 & 80.00 & 7.1 \\
\hline 17 & 840.00 & 100.00 & 11.9 \\
\hline 18 & 840.00 & 100.00 & 11.9 \\
\hline 19 & 740.00 & 15.00 & 2 \\
\hline 20 & 740.00 & 15.00 & 2 \\
\hline 21 & 790.00 & 50.00 & 6 \\
\hline 22 & 740.00 & 70.00 & 9 \\
\hline 23 & 220.00 & 50.00 & 22.7 \\
\hline 24 & 270.00 & 50.00 & 18.5 \\
\hline 25 & 1330.00 & 225.00 & 19 \\
\hline 26 & 280.00 & 200.00 & 71 \\
\hline 27 & 2270.00 & 30.00 & 1 \\
\hline 28 & 820.00 & 80.00 & 9.1 \\
\hline 29 & 740.00 & 41.00 & 5.5 \\
\hline 30 & 790.00 & 50.00 & 6 \\
\hline 31 & 3480.00 & 286.00 & 8 \\
\hline 32 & 20.00 & 20.00 & 100 \\
\hline 33 & 200.00 & 60.00 & 30 \\
\hline 34 & 1040.00 & 40.00 & 3.8 \\
\hline
\end{tabular}

and food mats have to be quite long, whereas shorter lengths are adequate for making food baskets and sitting mats. There are several streams in Khanyayo from which imizi are harvested. In order of popularity, these streams are Malola, Mtentu, Mbandani, Dlamula, Ludaleni, Mpisini, Mangciza, Nciba, Isizweni, Makhulu, Mngoncweni and Mzimkhulu. About 75 per cent of respondents harvested from Malola and Mtentu.

Just over half the respondents (27, or 52 per cent) owned imizi gardens. With the exception of two, all these garden owners only had one garden each. Most of the gardens owned by 
these respondents (23, or 44 per cent) were located along the streams, in what can be described as common lands, while two were located at home. However, two of the respondents owned gardens both at home and along the streams. Most of the imizi gardens along the streams had clear boundaries. The size of the gardens ranged from about 10 to 65 square metres. Most of the gardens found along the streams (common lands) tended to be of equal size and with neat divisions. Thirty-seven respondents (about 71 per cent) who harvest said they harvest imizi from the gardens along the streams, seven from their home gardens, and five both at home and along the streams (see Table 4).

As indicated earlier, there were also those (25, or 48 per cent) who did not own imizi gardens. These people obtain imizi either by asking garden owners for it, whereby the non-owner provides the labour to harvest for both the owner and him/herself, by stealing, or by harvesting from the few gardens found along the streams that are not owned by anyone. At least 34 (65 per cent) of the respondents knew of imizi gardens that were not privately owned, and could be accessed by anyone. These were generally located in or near the Mtentu River. One reason given by respondents for the existence of these gardens without owners is that there were rumours that izithunzela (ghosts) resided in the forests close to the Mtentu River, making it unattractive to many would-be owners. In this case only the brave or those who did not believe in ghosts benefited from these gardens without owners. The other category of gardens that are not owned is that of abandoned gardens. When a garden has not been claimed for a number of years, any person who takes care of it could legitimately claim it as theirs. However, as Kepe (2003) points out, this often results in conflicts when the original owner or their kin reappear to reclaim the garden.

In cases where producers have gardens both at home and on common land along the streams and rivers, the garden located at home tends to gain preference. By the same token, the one located on common land, further away from the home, tends to be comparatively neglected. One of the respondents, Princess, is an example of a producer who has gardens both at home and on common land (Malola). She planted her home garden in September 1998 and by April 2000 the garden was a success. To achieve this success she invested in the garden through careful weeding and regular watering. However, since she started harvesting imizi from her home garden in 2000 she has gone to her Malola garden only once, which was in 2002. She claims that besides the distance to the Malola garden, theft by other villagers was another discouraging factor.

However, the interviews also revealed that while there were several reasons why it was advantageous to have a home garden, such as its being closer to the owner's home and thus easy to protect from animals and theft by other villagers, there are also disadvantages associated with home gardens, the two main ones being that an imizi garden tends to attract snakes, and that regular watering is needed, which is not the case with gardens near streams.

Table 4: Harvesting sites by numbers of respondents

\begin{tabular}{llrr}
\hline Location & Property regime & $\begin{array}{c}\text { Number of } \\
\text { collectors (n= 49) }\end{array}$ \\
\hline Along the streams & Communal & $76 \%$ & 37 \\
Home & Private & $14 \%$ & 7 \\
Along the streams and home & Communal and private & $10 \%$ & 5 \\
Total & & $\mathbf{1 0 0 \%}$ & $\mathbf{4 9}$ \\
\hline
\end{tabular}


Irrespective of the location of the imizi garden, there are several other challenges associated with collecting imizi. First, the imizi have sharp edges that could result in painful cuts on both legs and hands during harvest. Almost all the respondents (51) wore gumboots to protect their feet, but only one wore gloves to protect the hands. Secondly, many of the harvesters (21) said they often suffered from back pains from bending during harvesting. Thirdly, 32 of the respondents claimed to have encountered snakes during harvesting. As mentioned earlier, some people also mentioned being scared of ghosts when they harvested in gardens located far from their homes. At least 21 of the respondents harvest alone, while the rest get assistance. Of those who are assisted, most (22) receive assistance from family members, and two are assisted by a group of friends or work-parties.

The majority of the harvesters (35) harvest imizi to make woven products, while seven of them harvest it both for craft making and for sale. Those who harvest it for sale said they only sell when someone approaches them to buy, which does not happen often. Only one respondent - Marhadebe - sold imizi at the 'pension market' (stalls set up at the points where people collect their government grants) but also said that she did not take imizi to market every month. Marhadebe's monthly trips to the local pension market are mainly to sell mats that she makes. It is only through a pre-order system and, of course, having a surplus after her own weaving requirements that she also sells imizi at the market. Some customers are willing to collect the material from her house. Almost all the customers who buy imizi are local villagers.

\subsubsection{Access to rights over $C$. textilis (imizi)}

As mentioned earlier, owning an imizi garden is the most common way of accessing the raw material used for crafting mats and baskets. More than half the garden owners inherited gardens from relatives (Kepe, 2003). Owning such a garden is considered the most secure way to ensure rights of access to this resource. The 25 respondents who did not own gardens gained entitlements (see Leach et al., 1999) to imizi in a number of ways. First, people can buy them using cash. A bunch of imizi that is enough for making a sitting or sleeping mat costs between R20 and R30. Secondly, people can gain rights of access to imizi by exchanging their labour, either by harvesting or weaving for the garden owner as well as themselves. Thirdly, craft makers can gain entitlement to the raw material through reciprocity. In this case people whose homes are close to the streams where imizi gardens are located are allowed to harvest up to 50 per cent from the owner's garden. This is often done after an arrangement had been reached, whereby they agree to look after the owner's garden. Even then, the non-owner must still ask for permission whenever they collect. Fourthly, others simply ask for charity. More often than not, it is either relatives or the very poor who gain rights through charity. Fifthly, as stated above, gardens located in areas that are avoided by the locals (e.g. for fear of ghosts) and thus have no owners, become another way for non-owners to gain entitlements to imizi. Lastly, theft has increasingly become another strategy to access imizi. Twelve respondents claimed they had had imizi stolen from their gardens. Such incidents of theft occur mainly in gardens located along the streams, far from the residential areas, and where there is no one to guard it.

\subsubsection{The process of weaving}

The making of mats and baskets from imizi requires intricate skills. Sixteen respondents had acquired these skills from their mothers, and 13 had been taught by other relatives 
Table 5: Source of weaving skills acquired

\begin{tabular}{lrr}
\hline Source of skills & \multicolumn{2}{c}{$\mathbf{n = 4 3}$} \\
\hline Taught by mother & $37 \%$ & 16 \\
Taught by other relatives & $30 \%$ & 13 \\
Taught by grandmother & $12 \%$ & 5 \\
Taught by friend & $9 \%$ & 4 \\
Taught by neighbour & $5 \%$ & 2 \\
Taught by spouse & $2 \%$ & 1 \\
Learning by observation & $5 \%$ & 2 \\
Total & $\mathbf{1 0 0 \%}$ & $\mathbf{4 3}$ \\
\hline
\end{tabular}

(see Table 5). Before weaving, the weaver takes the imizi and either wraps them in moist material or spreads them carefully outside if it is raining. This is done to make them more pliable. Imizi are, however, not used alone when weaving. Other materials are used, such as twine for holding the mats and baskets together and for decoration. Often this is wool, or string from mesh bags for cabbages or oranges, or strips of plastic shopping bags. If the twine has to be purchased, a bundle needed for weaving about 20 mats costs about R30. Villagers note that in the past they used twine made from tree bark or branches (iminxeba). They argue that these days it is more cost-effective, in terms of time, to use the synthetic alternative sources of twine.

It takes anything from one to five days to finish a basket or a food mat, and five to 15 days to make a sleeping or sitting mat, all depending on how fast the weaver works and how much time she allocates to this activity per day. Applying intricate decoration means it takes longer to complete the products, so those intended for home use are often only minimally decorated.

\subsection{Trading of mats and baskets}

Many of the producers had been weaving the products for most of their lives, but not for purposes of trading. One producer, who is 60 years old, claims to have started weaving when she was a teenager. She says she made articles mainly for home use and to give as gifts during traditional ceremonies (see Kepe, 2003) and only started selling her products in 2001 as there was no market for imizi when she was younger.

Among those who said they did not trade are other producers who use some of their products as a token of appreciation or apology to others. For example, when Mamphindelwa's son was sick, her neighbour's daughter, Nophindile, used to come and help her with household chores, as she spent most of her day taking care of her son. Nophindile was not being paid, nor was she expecting anything from Mamphindelwa. After the death of her son, Mamphindelwa wove several mats and gave them to Nophindile to show her how much she appreciated what she had done for her.

Another example is that of Mamlalisweni, who owns a lot of livestock and only weaves products for home use and to give as gifts. However, on one occasion she found herself weaving for a different purpose. One day her cows ate another villager's crops, but the owner of the crops did not report the matter to the chief as he had a close relationship with Mamlalisweni. This gesture made Mamlalisweni feel indebted to him. She then 
decided to weave baskets and offered them to him as a peace gesture, apologising and also appreciating that he did not report the matter to the chief.

However, there are many weavers in Khanyayo who do produce to sell. The majority of the weavers in this study (30, or 58 per cent) did so (see Table 6). Table 7 shows that of these six had been in the business of selling mats and baskets for 20 years or more, four had been selling for at least ten years and nine for about five years. However, most of them (16) had been in the business for less than five years. All the respondents made the products they sold themselves.

Producers had different reasons for entering the industry. The most popular reason, offered by 17 respondents, was that the producer needed to supplement other sources of household income, while nine said they simply needed something more dependable as a source of cash income. Another nine argued that they were driven to crafting by poverty (see Table 8). Common among many of these women was the fact that they had either lost their husband or the husband was unemployed. Before entering the trade, the 13 respondents were unemployed and 13 were selling other products (see Table 9).

The majority of traders (26) sell their products mainly from home. The system they use is to continue weaving and storing the goods at home until the customers approach them. Other customers place orders and state the date of collection. Eight of the respondents sell at the local pension market on a regular basis, in addition to selling from home (see Table 10). Only one respondent sells from home, at the pension market and at the town market in Flagstaff $(60 \mathrm{~km}$ away). This one respondent was born in Flagstaff and she said she was used to the way of life in town. The rest of the respondents expressed a fear of going to town, arguing that life in town is too fast and that it is expensive for them to travel to and from town.

When respondents who sell from home and pension markets were asked if they would consider expanding their businesses and perhaps go and sell in town or at other

Table 6: Purpose of weaving handicrafts

\begin{tabular}{lrr}
\hline Purpose of weaving & $\mathbf{n}=\mathbf{4 2}$ \\
\hline Give them as gifts, use at home and sell for cash & $70 \%$ & 30 \\
Give them as gifts and for home use & $23 \%$ & 10 \\
Sell them and give as gifts & $7 \%$ & 2 \\
Total & $\mathbf{1 0 0 \%}$ & $\mathbf{4 2}$ \\
\hline
\end{tabular}

Table 7: Period of involvement in the crafting trade

\begin{tabular}{lrr}
\hline Period of involvement & $\mathbf{n = 3 5}$ \\
\hline Less than 5 years & $46 \%$ & 16 \\
More than 5 years & $26 \%$ & 9 \\
More than 10 years & $11 \%$ & 4 \\
More than 20 years & $17 \%$ & 6 \\
Total & $\mathbf{1 0 0 \%}$ & $\mathbf{3 5}$ \\
\hline
\end{tabular}


Table 8: Reasons for entering the trade

\begin{tabular}{lrr}
\hline Reason for trading in crafts & $\mathbf{n}=\mathbf{3 5}$ \\
\hline To supplement other household income & $48 \%$ & 17 \\
Needed another source of income to depend on & $26 \%$ & 9 \\
Poverty & $26 \%$ & 9 \\
Total & $\mathbf{1 0 0 \%}$ & $\mathbf{3 5}$ \\
\hline
\end{tabular}

pension markets, the majority (25) said they would not, while nine said they would consider it if time and money allowed (see Table 11). Old age, other household chores and the limited number of customers were given as the main reasons why respondents did not consider expanding their trade in the future.

The trading of mats and baskets takes place throughout the year, and according to respondents business is best when there are traditional ceremonies such as the girls' initiation ceremonies (umgubho or umngquzo) or when people are being taken out of mourning, following the death of their spouse or child. These ceremonies usually take place in June and December, thus coinciding with school holidays.

\subsubsection{Prices of mats and baskets}

The price of any woven product is determined by its size, decorations and the selling point. Thus, for example, bigger or intricately decorated mats or baskets, or those sold at the pension market rather from the producer's home, will cost more. In 2004 baskets were priced from R5 to R25 when sold from home and from R10 to R30 when sold at the pension market; food mats from R5 to R30 when sold from home and from R5 to R35 at the market; sitting mats from R8 to R40 when sold from home and from R20 to R70 at the market; and sleeping mats from R35 to R70 when sold

Table 9: Previous occupation of traders

\begin{tabular}{lrr}
\hline Occupation & & $\mathbf{n}=\mathbf{3 5}$ \\
\hline Unemployed & $40 \%$ & 14 \\
Trading other items & $37 \%$ & 13 \\
Employed & $6 \%$ & 2 \\
Attending school & $3 \%$ & 1 \\
Other & $14 \%$ & 5 \\
Total & $\mathbf{1 0 0 \%}$ & $\mathbf{3 5}$ \\
\hline
\end{tabular}

Table 10: Marketing bases

\begin{tabular}{lrr}
\hline Marketing base & $\mathbf{n}=\mathbf{3 5}$ \\
\hline Home & $74 \%$ & 26 \\
Home and pension market & $23 \%$ & 8 \\
Home, pension market and town market & $3 \%$ & 1 \\
Total & $\mathbf{1 0 0 \%}$ & $\mathbf{3 5}$ \\
\hline
\end{tabular}


Table 11: Expansion of trading activities

\begin{tabular}{lrr}
\hline Would you consider expanding the business? & \multicolumn{2}{c}{$\mathbf{n = 3 4}$} \\
\hline Yes & $26 \%$ & 9 \\
No & $74 \%$ & 25 \\
Total & $\mathbf{1 0 0 \%}$ & $\mathbf{3 4}$ \\
\hline
\end{tabular}

from home and from R35 to R75 at the market. The small differences in price between products sold at home and those sold at the market were to factor in transport costs. However, respondents who went to sell at the market pointed out that some customers would negotiate the prices down to a point where they would be the same or lower than the home selling prices. Out of desperation the traders would, more often than not, take the price offered by the buyer, even if it was much less than they had hoped for.

\subsubsection{Income received from the trade in mats and baskets}

As shown in Table 2, the amount of money made per month by mat and basket traders ranged from R30 to R360, with the mean monthly income being about R58 $(\mathrm{R} 57.5 \pm 14.28)$. The income earned from these sales was little compared with other sources of household income, and not many respondents considered it the most important source of income. The income earned by producers varied according to the level of their involvement in the trade. Traders who traded both at home and at the pension market mostly earned between R251 and R300 per month (see Table 12), a higher average income than those who only sold from home.

\subsubsection{The contribution of the trade to household livelihoods}

The contribution of this trade to local livelihoods varies depending on how much is actually being produced. Most producers (16) used the money they earned from selling mats and baskets to buy food, and 15 used it to buy food and clothes and to pay school fees. Five used some of the money to buy other goods to sell - these respondents either had a 'tuck-shop' (convenience store) at home or needed to pay the costs of travelling to Durban to sell medicinal plants (see Table 13). Even though the importance of this income was emphasised, it was made clear by all respondents that it mainly served to supplement other livelihood strategies.

Table 12: Household income from handicrafts per month

\begin{tabular}{lrr}
\hline Household income from handicrafts & \multicolumn{2}{c}{ Percentage } \\
\hline R0-R50 & 47 & 16 \\
R51-R100 & 35 & 12 \\
R151-R200 & 10 & 3 \\
R251-R300 & 9 & 3 \\
Total & $\mathbf{1 0 0}$ & $\mathbf{3 4}$ \\
\hline
\end{tabular}


Table 13: Use of money from handicrafts

\begin{tabular}{lrr}
\hline Use of cash & \multicolumn{2}{c}{$\mathbf{n = 3 6}$} \\
\hline Buy food & $43 \%$ & 16 \\
Buy food, clothes and pay school fees & $41 \%$ & 15 \\
Buy food and other goods to sell & $14 \%$ & 5 \\
Total & $\mathbf{1 0 0 \%}$ & $\mathbf{2 6}$ \\
\hline
\end{tabular}

\subsection{Challenges associated with crafting-related livelihoods}

Almost all producers said the mat and basket trade involves several difficulties. The first complaint was that there are few customers and it is usually a long time before a customer comes to buy again. The second was that it is now popular for customers to buy on credit and most of them take too long to pay. According to one respondent, 'Customers who buy on credit are a problem as they often take too long to pay, or pay in instalments, including people taking six instalments to pay for a R30 mat'. The traders argue that because of this they are not able to use the money as originally planned or budgeted. One trader observed, 'As a trader I have a lot of enemies because when I go to collect the money at the end of the month (especially with pension receivers), some customers say I am inconsiderate because I can see that they are living in poverty. We end up fighting as I would also tell them that I need money as I am also poor'. Other common problems that were mentioned were low prices, competition from other traders and the cost of raw materials. Competition amongst the traders for the few customers is cited as occasionally leading to conflict, entailing bad-mouthing the other trader's products in the hope that the buyer will buy one's own products instead.

\section{CONCLUSIONS}

The article has shown that plant-based craftwork from $C$. textilis makes a significant contribution to local people's diverse and multiple livelihood strategies. More specifically, it is an important contributor to a fairly diverse rural livelihood portfolio that includes the land-based strategies of arable farming, livestock husbandry, the consumption of and trade in natural resources and off-farm sources of income such as migrancy, government grants and employment. While gradually being acknowledged in research and policymaking circles, the trade in plant-based craftwork has been poorly understood. Using the case study of the Khanyayo community in the Eastern Cape Province, this article contributes to a better understanding of the trade in craftwork.

Three key observations were made. First, the mat and basket trade is dominated by middle-aged to older women, who are often widowed or come from poor households. Secondly, the extent of the contribution of crafting to rural livelihoods is dependent on the extent to which the trader is involved in this industry. This study has shown that many of the households involved in crafting do not feel their investment in this activity can cover their livelihood requirements completely; thus they divide their time between crafting and other livelihood strategies. It is therefore important to note that even though the use and commercialisation of these mats and baskets are important in local livelihoods, they do not replace other sources of income or rural livelihood strategies. This is something that should be acknowledged by policy makers, practitioners and researchers concerned with rural livelihoods in South Africa. Third, traders involved 
in the mat and basket trade in the study area face numerous challenges, which include local people taking products on credit, oversupply of the products at the market and poor access to the markets where business might be better. While these are challenges, they also present opportunities for the state and other agencies to make a positive intervention for the good of the rural poor. As Shackleton et al. (2001) suggest, there is a need for the government to have flexible policies on land and natural resources, as well as various infrastructural developments that will enhance rather than restrict the value that can be derived from natural resources by poor people in rural areas.

\section{REFERENCES}

CAWE, SG \& NTLOKO, SST, 1997. Distribution, uses and exploitation patterns of Flagellaria guineensis Schumach. with particular reference to Port St Johns, South Africa. South African Journal of Botany, 63(4): 233-8.

CUNNINGHAM, AB, 1987. Commercial craftwork: balancing out human needs and resources. South African Journal of Botany, 53(4): 259-66.

HEINSOHN, RD \& CUNNINGHAM, AB, 1991. Utilisation and potential cultivation of the Saltmarsh Rush Juncus Kraussii. South African Journal of Botany, 57(1): 1-5.

HUNTER, M, 1979. Reaction to conquest: effects of contact with Europeans on the Pondo of South Africa. Abridged edition. Cape Town: David Philip.

KEPE, T, 2002. Grassland vegetation and rural livelihood: a case study of resource value and social dynamics on the wild coast, South Africa. $\mathrm{PhD}$ thesis, University of the Western Cape.

KEPE, T, 2003. Use, control and value of craft material - Cyperus textilis: perspectives from a Mpondo village, South Africa. South African Geographical Journal, 85(2): $152-7$.

LEACH, M, MEARNS, R \& SCOONES, I, 1999. Environmental entitlements: dynamics and institutions in community-based natural resource management. World Development, 27(2): 225-47.

MARCUS, T, 2000. Crafting in the context of AIDS and rural poverty: a livelihood strategy with prospects. Transformation, 44:17-35.

MAY, J, 2001. Meeting the challenge? The emerging agenda for poverty reduction in post-apartheid South Africa. In Wilson, F, Kanji, N \& Braathen, E (Eds), Poverty reduction: what role for the state in today's globalized economy? Claremont: New Africa Education Publishing, pp. 460-496.

ROGERSON, CM \& SITHOLE, PM, 2001. Rural handicraft production in Mpumalanga, South Africa: organization, problems and support needs. South African Geographical Journal, 83(2): 149-158.

SHACKLETON, CM \& SHACKLETON, SE, 2000. Direct use values of secondary resources harvested from communal savannas in Bushbuckridge, Lowveld, South Africa. Journal of Tropical Forest Products, 6(1): 28-47.

SHACKLETON, CM, SHACKLETON, SE \& COUSIN, B, 2001. The role of land-based strategies in rural livelihoods: the contribution of arable production, animal husbandry and natural resource harvesting. Development Southern Africa, 18(5): 581-604. 